УДК-821.133.1

DOI: $10.24144 / 2617-3921.2020 .18 .229-239$

Наталія Баняс

кандидат філологічних наук, дочент Закарпатський угорський інститут імені Ференцุа Ракоиі II orcid.org/0000-0002-6974-0790

м. Хуст, Україна, +38 (096) 917-18-00, nybanias@ gmail.com

Володимир Баняс

кандидат філологічних наук Закарпатський угорський інститут імені Ференй Ракоиі II orcid.org/0000-0001-6880-8805 м. Київ, Україна, +38 (096) 917-18-01, baniasvv@ gmail.com

\title{
Лейтмотиви роману «Погляд Медузи» Сільві Жермен
}

Анотачія. У запропонованій статті розглядається роман «Погляд Медузи» Сільві Жермен - один із ключових творів письменниці, яка належить до найбільш знакових у сучасній франиузькій літературі. Як $і$ в усіх ї̈ попередніх романах та в більшості подальших, у иьому ключовим елементом літературної гри $\epsilon$ функиіонування різних лейтмотивів. Головною ж особливістю функціонування лейтмотивів у романі «Погляд Медузи» є як адаптація поширеного мотиву Горгони, так $і$ увиразнення дитячого світу дитини (дівчинки). Стосовно творчості Сільві Жермен можемо говорити про «лейтмотивну свідомість» як щось виокремлене й самодостатнє, оскільки саме в структурі лейтмотивів думка розвивається певною мірою незалежно. В обраному романі спостерігається логічна фіналізація лейтмотивів очей, Бога, сну, тіла та ін., які зустрічаються в усіх попередніх творах Сільві Жермен та в більшості подальших. Мотив Горгони є дуже характерним для франиузької літератури, в контексті якої роман «Погляд Медузи» сприймається діалогічно. Поетика погляду Медузи у романі тягне за собою величезну традииію змістових трансформачій, є однією з модифікацій великого мотиву світової літератури. Тож лейтмотив погляду Медузи можна розглядати в контексті всієї франиузької літератури, фактично він $і$ стає лейтмотивом лише в цььому контексті. Гастон Башляр розглядав погляд Медузи, як своєрідний комплекс, представлений у франиузькій літературі. На його думку, комплексом Медузи були перейняті твори Проспера Меріме, Жана Лескюра, Еліаса Льоннрота, Пьєра Емманюєля, Гюїсманса та ін. Характерним змістом комплексу Медузи у франиузькій літературі стає скам'яніння. Ненависний людожер у романі Сільві Жермен також скам'янів під поглядом маленької Люсі.

Ключові слова: лейтмотив, очі, Бог, тіло, сон. 
Abstract. In this article, it is being considered the novel «The Medusa Child» by Sylvie Germain - one of the key works of the writer that is among the most iconic in modern French literature. Just as in all of her previous novels and in most subsequent ones, in this novel the key element of the literary game is the functioning of various leitmotifs. The main feature of functioning of leitmotifs in the novel "The Medusa Child》 is both the adaptation of the common motive of Gorgon and the expression of the child's world of the girl. Regarding the works of Sylvie Germain, "leitmotifs consciousness» is something isolated and self-sufficient, since it is in the structure of leitmotifs the thought is developing to a certain degree independently. In the given novel, it can be observed a logical finalization of the leitmotifs of the eyes, God, sleep, body, etc., which can be found in all previous works of Sylvie Germain and in most subsequent ones. The actualization of the leitmotifs of the eyes in the novel "The Medusa Child» is due to the semantic filling of the image of the Gorgon, the signs of which are partially transferred to Lucy, a little girl. Therefore, the semantic development of the leitmotif of the eyes in the novel is objectively exaggerated, it is expanded in accordance with its own mytheme space and has a centering function in the text with respect to the leitmotif structure of the novel. All of Lucy's innermost thoughts are revealed to the reader only in the leitmotif space. The usual life events are conveyed in the work at the thematic and plot level. This distribution of the information field of the text contributes to the formation of two planes - the reality and the world of the mythological Gorgon. Lucy, being in both worlds at the same time, is not able to coordinate these worlds by herself, however, she is the only creature that is present in both worlds at once. Germain's mystification of the text at the leitmotif level in this novel is also distinguished by emphasizing on probability-reliability as a shaky facet of human consciousness. There is even a game underway with this facet. Reality and mysticism are always mutually conditioned in the same way as they are mutually denied.

Keywords: leitmotif, eyes, god, body, dream.

Вступ. Роман «Погляд Медузи» (1991) сучасної французької письменниці Сільві Жермен відрізняється від усього, що вона написала попередньо. Насамперед вражаючою $є$ тематична відмінність, адже це роман про дитячу душу, написаний з позицій маленької дівчинки, яка зазнала згвалтування. Здавалось би, що й лейтмотивна структура в такому творі мусить надзвичайно різнитися від попередніх, але саме на рівні лейтмотиву відмінності мінімальні, адже в романі виринають змістовно ті самі лейтмотиви, що і в попередніх творах: очі, тіло, плоть, смерть, Біблія, Бог тощо. Всі лейтмотиви семантично виструнчуються й утворюють таку значеннєву ієрархію, яка не повторює попередньо заявлені, тобто при всій однотипності заявлених лейтмотивів у романі «Погляд Медузи» пропонується їх оновлений розвиток.

Методологія та методи дослідження. Автори взяли на озброєння тематологію та філософію літератури, а також герменевтику та наратологію. Переваги надали женевській школі критики свідомості, представленої в 
працях Г. Башляра, Ж.-П. Вебера, Ж. Пуле, Ж.-П. Рішара, Р. Труссона та ін. Враховуємо також досягнення методики аналізу тексту на рівні лейтмотивів, запропоновану М. Бахтіним, О. Веселовським, Б. Гаспаровим, О. Жолковським та ін. Спираємось також на теоретичні розробки Ю. Борєва, Н. Висоцької, О. Галича, В. Жирмунського, Ю. Лотмана, Д. Наливайка, А. Ткаченка, В. Халізєва, В. Фесенко та ін., в яких лейтмотив не завжди ставав акцентованою проблемою літературознавства, проте осмислено закономірності літературного розвитку.

Мета дослідження полягає у згрупуванні та 3'ясуванні специфіки функціональності та змістовності виявлених лейтмотивів у названому романі Сильві Жермен, зокрема, у відтворення структури лейтмотивів та систематизації найуживаніших (провідних) із-поміж них.

Виклад основного матеріалу дослідження. Перейдемо безпосередньо до розгляду лейтмотивів у романі «Погляд Медузи».

Лейтмотив очей. Особливо актуалізованим у романі є лейтмотив очей. Дві основні значимі площини, в яких він еволюціонує, пов'язані з космосом і 3 помстою, є такими, що виключають одна одну. Очі, що ладні розгледіти найменші дрібнички у космосі, - бінокль - відкривають Луї-Феліксу новий світ: «Йому подарували чарівні очі, здатні бачити невидиме, розглядати те, що знаходиться поза землею, потрапляти за куліси світу» [2, с. 13]. 3 одного боку, дитячі очі, які можуть бачити невидиму структуру світу, приховану від звичайної людини, від світу дорослих, з другого - очі ображеної дитини, які сягають глибин душі, щоб відшукати там спокій і порятунок. Друга площина семантики очей розвивається стосовно образу маленької Люсі.

Лейтмотив очей маленької Люсі втілив ідею дитячої помсти людожеру. Ця площина семантики лейтмотиву очей розвинена набагато більше, ніж позитивна космологічна семантика очей Луї-Фелікса. Семантичний ряд лейтмотиву очей ображеної Люсі виструнчується таким чином: очі дитячі погляд - пристріт - магічне око - очі Горгони - смерть. Очі стають єдиним знаряддям помсти згвалтованої братом Люсі. Ї̈ї гвалтівник стає нерухомим, єдине, на що він спроможний, це - бачити світ, в якому йому відведено лише функцію спостерігача. Тож йому залишився лише погляд. Люсі отруює йому й цю маленьку можливість доторкання до світу. Вона перетворюється на химеру, що оселяється в погляді брата-гвалтівника. Маленька дівчинкаангелятко перетворюється на страшну химеру, що переслідує злочинця, оскільки вона одна знає про його злочини, вона була втягнена в смертельну змову з вбивцею маленьких дівчаток. Химера, в яку перетворюється Люсі, то іiі єдиний дитячий захист від злочину, в якому вона була не лише жертвою, а й співучасницею, оскільки так і не змогла нікому сказати, що ії рідний брат, красень Фердинан, і $є$ гвалтівником та вбивцею маленьких дівчаток. Єдине, що могло промовляти до світу людей, що не міг відібрати у неї іiі кат, - це був погляд. Тож саме у площині погляду, очей і розгортається дитяча помста. Гіперболізація можливостей очей, нагнітання магічної змістовності навколо 
них поступово стає сферою реальності для Люсі. Якщо їй не залишається нічого, окрім погляду, вона зробить цей погляд страшнішим за будь-що в світі, зробить його катом свого гвалтівника.

Поступово Люсі наділяє очі магічною силою, переконує себе, що навіть очі жаб є носіями цієї магічної сили природи, яка так вабить іï, як сфера іiі єдино можливого «промовляння». «Очі! Ось що так захоплює Люсі у жаб і метеликів: обидва ці види живих істот в процесі різноманітних метаморфоз перетворюються на очі. Випуклі кулі кольору болота й міді, що виглядають 3 трави й стоячої болотної води, великі, картаті, як калейдоскоп, квіти, що пурхають в повітрі, тужливі плачі кольору осені, які важко летять вночі, такими видавались жаби, нічні й денні метелики дитині, від якої залишились лише очі» [2, с. 131-132]. Люсі покидає всіх своїх друзів, відвертається від рідні, єдиним другом для неї стають ці очі, які, на їі думку, свідчать про те, що жаби й метелики знають про все і все розуміють. Жаб'ячі очі стають для неї магічним оком природи, в якої вона навчається. Люсі опановує смертельним поглядом Медузи, тобто Горгони: «І переможений людожер відчуває, з жахом відчуває, що ніколи йому не втекти від погляду величезних очей ворожбитської дитини, в яких сплавлені мука й ненависть, потворність і краса. Бо це погляд Медузи» [2, с. 144]. Містичне перетворення Люсі $є$ камерним 3 огляду на те, що ніхто його не помічає, ніхто не знає, що маленька дівчинка стає катом для свого брата-злочинця. Все, що відбувається з Фердинаном, може бути прояснене логікою реальності, хворобою тощо, але для Люсі реальність зникає, вона живе у світі магічних перетворень плоті під тиском смертельного погляду Медузи. Вона використовує цей погляд, щоб вбити людожера.

Чим довше страждає Фердинан, тим більше оточуюча його рідня дбає про його одужання, особливо мати, яка навіть відвідує ворожку, щоб та зняла вроки з її улюбленого сина. Таке раптове повернення до магічного боку життя матері Люсі значно збільшує магічну семантику описуваної події. Фактично, вся родина опиняється в полі дії магії, чарівних засобів впливу на людську плоть. Алоїзі, матері, вдалось встановити, що іiі син став жертвою вроків: «...Той, хто навів вроки, мав величезну силу і його зловіще чорне око потрапило в найглибші куточки душі Фердинана, вивершуючи свій згубний вплив» [2, с. 152]. Страшна сила погляду маленької Люсі не покидає іiї разом зі смертю іiі ворога. Перемігши людожера, дівчинка одержує у спадок страшний погляд Горгони. Такий містичний дарунок обтяжує Люсі, але вона не може позбутись його. Магічна помста залишила на ній чорний відбиток мороку.

Погляд смерті потребував спокути, Люсі зазнає безліч втрат, мандрує світом, щоб вгамувати цей болісний погляд - дарунок іï дитячої помсти. Врешті, вона позбавляється його у хвилину свого каяття: «Гроза, що відходила, і вітер понесли в синьо-фіолетових складках хмар погляд дівчинки, яка довго була одержима ненавистю й страхом, а потоки дощу змили й понесли 
маску Медузи, яку остання слабка блискавка щойно вирвала 3 дитячого серця» [2, с. 263]. Містична історія дитячої помсти завершується так же ірреально. Природа, що наділила Люсі магічним вбивчим поглядом, позбавляє іiї цього страшного дарунку. Цей погляд став не лише символом помсти беззахисної дівчинки перед людожером, а й ії власною тортурою, оскільки здійснивши жадану помсту, Люсі страждає від втрати почуття радості від того, що магія вплинула на її тендітну душу й позбавила щастя людського спілкування, щастя дитинного світовідчуття тощо.

Звернення до містики, як форми художнього становлення змісту, в романі зумовлене попередньою традицією французької, та й світової, літератури. Обертання в межах існуючих традицій містифікації тексту, втім, не зробило прозу Сільві Жермен наслідувальною, вона лише засвідчує наступність певної художньої ідеї, приналежність до неї. Особливо характерна була містика для літератури доби модерну, зокрема для французьких символістів тощо. Петер Козловскі зазначав: «Філософські системи модерну не лише міфологічні, але й пройняті магією; вони припускають можливість засобами магії однією-єдиною людською думкою підкорити весь світ владі пануючої над ними філософської ідеї» [3, с.175]. Філософія й магія в модерні органічно об'єднані і стали запорукою інтелектуального розвитку художнього тексту. Цей здобуток модернізму й бере на озброєння Сільві Жермен.

Лейтмотив Бога. Лейтмотив Бога в романі «Погляд Медузи» значно трансформується щодо заявленого у попередніх творах концепту внаслідок накладання на нього дитячого світобачення. В творі представлено два дитячих сприйняття Бога: Луї-Фелікса й Люсі. Для Луї-Фелікса Бог є деміургом світу, який створив світ 3 нічого: «I цей безмежний всесвіт, який постійно розширюється, єдиний і всемогутній Бог сотворив з нічого» [2, с. 16]. Картини творення світу в уяві Луї-Фелікса ускладнюються наявністю античного пантеону богів, так би мовити, несправжніх богів, які існували до Одкровення істинного Бога. В його божественно-космологічну панораму всесвіту навіть антична міфологія логічно вплітається, одержує мотивацію: «Єдиний Бог розвіяв мрію, час заніс ці гнівні, погордливі й люті плоди. Але, йдучи у вигнання, переможені боги й богині розсіяли свої імена по всьому небу, наділили ними зорі й мандрівні тіла планет з кільцями кольору кіноварі вінками з каміння, льодових брил та пилу, покладеними на чоло богівкочовиків» $[2$, с. 16]. Властива хлопчику поетизація всесвіту поглинула містику творіння й велич Бога.

Сільві Жермен не лише інтерпретує божественну вісь світу з позицій дитячого світобачення, а й твердить про особливу наближеність дітей до опанування самим поняттям Божого Заповіту, який дітям надається від народження, а дорослі забувають його в суєті свого існування. «Милість Господня знову ховається в незриме, знамення завіту Його огортається в таємницю. І згадають про нього лише ті, хто здатен до терплячої праці пам'яті й мрії» [2, с. 29]. Винятковість дитячого відчуття божественності світу 
неодноразово наголошується в романі, всупереч існуючим уявленням про нерозвиненість дитячого сприйняття щодо апріорних понять, в тому числі й поняття «Бог». Тим самим Сільві Жермен відстоює містичну природу людини, як вроджену якість, як складову душі.

Сакралізація образу маленької Анни-Лізи, згвалтованої та вбитої людожером, в уяві Люсі базується на теологічних інтерпретаціях отця Жоашена, іiі вивченні катахизу та на внутрішній орієнтації на світлу радість Божественного Одкровення. Результатом всіх цих трьох впливів стало перетворення Анни Лізи на святу: «Анна Ліза тепер навіки Боже дитя. Тіло іiі опромінене німбом; тіло з чистого світла, в сто разів прекрасніше й легше за рожеву хмарку на сході дня» [2, с. 57]. Уявлення про святість, як про особливе сяйво, для Люсі є домінантою поняття «сакральне». В iï дитинстві реальність сакрального представлена в скульптурі Святого Антонія Падуанського, в історії життя Святої Люсії, в Святому Письмі, в тих його сторінках, які вона вже прочитала. Люсі ніде й ніколи не підіймається до бунту супроти Бога, навіть іiі дивна молитва до Святого Антонія Падуанського, молитва, в якій вона благає смерті підлому брату й просить, щоб всесильний Бог не дослухався до молитов їі близьких, що бажають життя Фердинану. Це молитва про смерть, що само по собі $є$ злочином супроти божественної природи світу, але не бунт супроти Бога.

Парадоксальні взаємини людини й Бога найкраще реалізовані в романі через образ Алоїзи, яка доходить до бунту супроти Бога, до ненависті до всього живого, до самої землі. Втрачаючи сина, Алоїза втрачає й цікавість до оточуючого їі світу, замикається в своїй втраті, духовно гине набагато раніше, ніж фізично. Винуватцем іiі горя вона бачить Бога: «Бога, який винуватець всього цього, який створив цю непостійну, непам'ятливу землю. Землю, яка носить і годує людей тільки для того, щоб легше було їх знищити, а потім пожерти. Бога, який, як твердять, подарував людині душу. Але що за дар ця душа, прищеплена до глухого й такого слабкого серця жалюгідних і нещасних людей? Хіба не міг Він залишити людей у спокої, наділивши їх блаженним глупством тварин, які не знають страждань любові, горя за померлими й жаху перед прийдешньою смертю?» [2, с. 219]. В той час, як дитинне сприйняття не заперечує Бога й існує у згоді 3 ним, сприйняття дорослого, обтяжене міркуваннями про сенс буття та життєві катаклізми, доходить до повстання супроти Бога, до нігілізму жити по-своєму, керуючись іншою правдою, аби дочекатись все ж таки щастя й спокою. Алоїза, зненавидівши Бога, зовсім його зрікається. Алоїза губить межу між містикою й реальністю, вона втягає Бога в свою реальність і хоче примусити Його діяти за їі власним планом, хоче воскресити Фердинана. Містичне світовідчуття Алоїзи суттєво різниться від Люсі тим, що вона занедбала вишуканість сакрального, не опанувала його всюдисущністю, силою власної волі Алоїза прагне переробити божественність світу, а не опанувати законами божественного. Для неї містика - це нагальне диво, диво на вимогу. Отже, Алоїза не розуміє природи сакрального, живе на 
периферії сакрального світовідчуття, iї віра в Бога взагалі є навіяною, вона не $\epsilon$ внутрішнім переконанням, жодна з їі молитов не доходить до божественного здійснення, на відміну від молитви Люсі, яка здійснюється.

Ці два розуміння Бога й божественності світу, два підходи до оперування містичним боком життя в романі співіснують, як паралельні світи. Кожному 3 персонажів ніколи не випадає потрапити у світ іншого, ані зрозуміти логіку світу іншого.

Лейтмотив Бога $\epsilon$ наскрізним не лише у романі «Погляд Медузи», а в інших, зокрема у романі «Безмірність» (1994). Він $\epsilon$ наскрізним мотивом всієї прози Сільві Жермен, проте у кожному наступному романі семантика лейтмотиву Бога значно змінюється. Задля з'ясування цих змін візьмемо до аналізу роман «Безмірність».

Особливістю розвитку лейтмотиву Бога в цьому романі $є$ те, що він індивідуалізується у відповідності до світовідчуття Прокопа Поупа. Провідною ж властивістю світовідчуття Прокопа $є$ пригніченість, соціальна образа, нереалізованість духовних прагнень. Якщо у романі «Погляд Медузи» Бог осмислюється, як очищаюче світло, як прихисток змученій душі героїні, то в романі «Безмірність» Бог відчужений від духовного світу персонажа, він ворожий, байдужий і холодний, він нічим не може йому зарадити. Герой вигукує: «Як записати чорним по білому неймовірне мовчання Бога?» [1, с. 191]. Прокіп не перебуває у діалозі з Богом, оскільки Бог для нього - мовчазна субстанція. Індивідуалізація Бога в світогляді Прокопа здійснена також внаслідок накладання образу дочки на образ Богоматері Марії. Страждання його дочки 3 нещасливої любові й страждання Богоматері сприймаються героєм в одному ряду духовних випробувань, яким годі й зарадити, й спостерігати які він далі не ладен. Отже, мотив Бога в романі «Безмірність» набуває ще більшої філософічності, пов'язуючись 3 проблемами самоусвідомлення Прокопа.

Лейтмотив тіла. Лейтмотив тіла в романі «Погляд Медузи» збагачується семантикою дитячої плоті та зганьбленої дитячої плоті. Перші роздуми Люсі над тілесністю світу виринають під впливом легенди про Святу Люсію, плоть якої зазнала глумління, оскільки вона видерла свої очі й послала ïx нареченому, за якого не хотіла виходити заміж, хоча Богоматір за велику iі любов до Ісуса подарувала ій нові гарні очі. Маленька Люсі приходить до висновку, що Свята Люсія мала дві плоті та двоє очей: одні святі, а другі мирські, і ніяк не може примирити в своїй свідомості це двоїння. Тоді вона вирішує, що подолати таке двоїння можна лише шляхом жаху: «Очі дивні й очі страдницькі, тіло, осяяне ореолом, й нещасна спаплюжена плоть, що вже гниє у землі. Очі, сповнені захоплення, і очі, сповнені жаху, прекрасне тіло ангела й жалюгідне зморене тільце. Люсі все намагалась зрозуміти, що об'єднує між собою ці очі, ці тіла; у неї з'явилось передчуття, що перетворення одного в інше повинне проходити через жах» [2, с. 82]. Загаданий у такий спосіб дуалізм плоті не долається в романі, а, навпаки, підсилюється. 
Після трагедії згвалтування Люсі перероджується, ï висока дитинна чиста плоть стає сплюндрованою і жалюгідною. 3'являються два образи Люсі, зафіксовані через спостереження iї власної матері. Перший образ Люсі: «Донька у мене просто справжній весняний протяг, тільки й дивись, щоб не застудитися, спостерігаючи, як вона стрибає то тут, то там» [2, с. 86]. Другий образ Люсі: «Моя дочка - справжня маленька гадючка, яка миттєво прослизає між пальцями і може вжалити, якщо посмієш наблизитися до неї. Я просто не знаю, з якого боку до неї підійти. Вона завдає мені багато турбот, і я не бачу 3 iï боку ні краплини ніжності!» [2, с. 86]. Весела, життєрадісна Люсі зникає назавжди, натомість з'являється Люсі 3 потьмареним світовідчуттям, приреченим на страждання й ненависть. Морок, який поглинає Люсі, ніхто не розуміє і не може ії порятувати, тому він осмислюється дівчинкою, як велика містична сила, супроти якої вона беззахисна.

Ще один змістовний відтінок концепту «дитяча плоть» пов'язаний зі сприйняттям самого людожера, для якого ця плоть $є$ звабною: «Вона була непокірлива і навіть бунтівлива, а вже ну просто до неймовірності, але все ж в цьому худому тілі ховалась прекрасна солодкість дитинства. Це тіло було йому покірним, належало йому, і було воно солодким» [2, с. 175]. Солодка плоть дитинства, з точки зору людожера, й становить суть звабного в дитячій плоті, за якою він полює.

Лейтмотив сну. Лейтмотив сну реалізується в романі як художня картинка власне сну і як теорія сновидінь, екзегетика сну. Сон і дитяча плоть дуже пов'язані між собою. Вперше опис сну стосується світовідчуття ЛуїФелікса: «Щоночі від засинає в ямці штучних небес і бачить сни, в яких сяє сонце, тремтять зірки або переливається північне сяйво. Уві сні він обертається навколо планет, летить, осідлавши сонячний вітер, перетинає Чумацький Шлях, бігає, подібно мисливцю за метеликами, безмежними просторами неба, ловлячи метеори» [2, с. 13]. Щасливе дитинство вундеркінда Луї-Фелікса дарує йому казкові сни про будову всесвіту, про космічний пил $\mathrm{i}$ зірки. Його покликання сягнути зірок реалізується спочатку в цих дитячих снах. Позитивна семантика сакралізованої дитячої плоті й радісних снів у романі поступово змінюється.

Зміні радісної й позитивної семантики сну, як відображення дитинного стану душі, сприяє звернення до теоретизування 3 приводу природи сну та можливостей впливу на людські сновидіння. Екзегетику сну черпає 3 роману Джоржа Дюморьє «Пітер Іббетсон» Алоїза, прагнучи перенестися у містичний світ, де загубилася душа їі сина. Сільві Жермен навіть наводить рядки з цієї книги: «Спати завжди треба лише на спині, підклавши складені руки під голову та схрестивши ноги - права лежить на лівій, якщо тільки ви не лівша; ні на мить не можна припиняти думати про те, де ви хочете опинитися уві сні, після того, як заснете; уві сні не можна ні на секунду забувати, де ви знаходитесь і ким станете, коли прокинетесь. Ви повинні поєднати сновидіння і реальність. Не забувайте про це!» [2, с. 149]. 
Алоїзі раптово відкривається істина, що сни непідвладні керуванню ззовні, що вона неспроможна орієнтувати своє несвідоме. «Дні йшли, сеанси сновидіння-реальності продовжувались, і плутанина все підсилювалась. Сеанси сновидіння-реальності не мали нічого спільного з тим, чим займались Пітер Іббетсон і герцогиня Тауер; то було швидше сновидіння-запаморочення або навіть сновидіння-морок. Заплутані марення Алоїзи заглиблювались у самі надра іiі плоті, і плоть розпалювалась, волала від жадання» [2, с. 162]. Зв'язок сну й несвідомих імпульсів душі виходить на поверхню, Алоїза плутає природу сну з природою розуму і тому потрапляє у пастку. Чорний морок все глибше засмоктує її: «Вона вийшла в похід, щоб порятувати сина, озброївшись материнською любов'ю і білою магією сновидіння-реальності, але в дорозі заблукала, дозволила, щоб нею оволоділа плотська любов, дала себе зачарувати чорній магії сновидіння-мороку» [2, с. 170]. Це $\epsilon$ містичне поринання засобом сновидіння, хоч Алоїза вороже ставилась до будь-якої містики, але у цьому випадку містика підкрадається до неї з того боку, де вона беззахисна.

Для Алоїзи сон стає другою реальністю, саме тією, якої їй не вистачало. У фрагментах опанування Алоїзою методики сну-реальності відчутна середньовічна традиція трактування снів як містка у минуле та майбутнє. У середньовіччя сон тлумачився як місток між життям і смертю, як відкритий кордон між ними, що спричинилось до численних описів подорожей у потойбіччя та спілкування з померлими для одержання від них різноманітних пророцтв та вказівок. Традиція інтерпретації сну як кордону між сучасним, минулим і майбутнім, сягає ще більш минувшини, тож видіння Алоїзи цілком утримуються в межах існуючої культурної традиції, виділяючись лише індивідуальними образами минулого. Специфікою письменницької манери Сільві Жермен є саме те, що вона не прагне винайти принципово новий художній елемент, а залучає його з культурних напластувань, вільно оперуючи різними століттями та епохами. Екзегетика сну, яка фактично дорівнює свідомій історії людства, обертається в ії романах то тим, то іншим змістовим боком, в залежності від художнього плану зображення, від потреб актуалізації образу. Сама ж письменниця ніякої нової теорії сну нам не пропонує.

Характерно, що сни Фердинана ніколи не бувають вивершеними картинами, вони взагалі безбарвні, в них немає нічого: «Він не заснув, і жодне сновидіння не угніздилось у ньому. А сон, що пливе всередині нього, такий дивний в чистому цьому світлі, що тремтить на небі, в якому губиться його беззмістовний погляд: небо повертається супроти обертання землі, на якій він розпростертий. Сон, що тисне його, стократ темніший, ніж фіолетові тіні, що затримались в гущавині живих загородок та заростей кущів» [2, с. 68-69]. Сон Фердинана межує з небуттям, в яке він повільно й переселяється. Позбавлення Фердинана сну 3 його яскравими картинами та звуками $\epsilon$ однією 3 характеристик цього образу, як позбавленого розуміння суті сущого, як людини, що вкрала дитинність світу, позбавила його барв і звуків. Таким 
чином, лейтмотив сну стосовно образу людожера також має функцію своєрідного вироку. Виключення Фердинана зі світу казкових видінь інтерпретується як покарання, як виключення його зі світу живих людей.

Сон у романі «Погляд Медузи» має семантику казкового одкровення світу, подарованого людям, добрим душею. Тож людожер просто не може мати такого дарунку, оскільки він руйнує світлу картину світу. Сон у романі стає ціннісним принципом, тобто втілює критеріологію цінності: тільки персонажі, які не вчинили злочину, ладні побачити казковий світ сну. Крім того, сон кожного персонажа індивідуалізується також у залежності від того, наскільки цей персонаж демонструє розуміння містичного боку життя, наскільки він затягнений у незбагненну подієвість неможливого, неймовірного. Цінність сну в системі містичного світобачення $є$ винятковою, тож, спираючись на вікові традиції тлумачення сну як чогось втаємниченого й вартісного, Сільві Жермен використовує прийом сну для того, щоб розставити акценти над образною системою роману, щоб допомогти читачеві зорієнтуватися.

Висновки 3 дослідження. Використання відомого у світовій літературі мотиву Горгони у романі Сільві Жермен потягнуло за собою низку семантичних значень, обійти які письменниця не могла та й не прагла, а саме: скам'яніння, холод, невідворотність перетворення тощо. Проводячи аналогію між дівчинкою та Горгоною, Сільві Жермен не лише увиразнює дитячу самотність та безвихідь, а й прагне задекларувати саму природу зла, його чинники. Все своє життя Люсі буде страждати від скоєного (як вона вважає) злочину, втратить природність у стосунках з людьми, набуде рис відчуження тощо. Лейтмотивна структура роману «Погляд Медузи» спрямована на демонстрацію прихованого, як, власне, i в усіх попередніх романах письменниці.

Актуалізація лейтмотиву очей у романі «Погляд Медузи» зумовлена семантичним наповненням образу Горгони, ознаки якої частково переносяться на Люсі, маленьку дівчинку. Тож семантичний розвиток лейтмотиву очей у цьому романі об'єктивно перебільшений, він виструнчений у відповідності до власного міфемного простору і має у тексті центруючи функцію стосовно лейтмотивної структури роману.

Всі сокровенні думки Люсі розкриваються читачеві лише у просторі лейтмотиву. Звичайна життєва подієвість передається у творі на рівні тематичному та сюжетному. Такий розподіл інформаційного поля тексту сприяє утворенню двох площин - реальності та світу міфологічної Горгони. Люсі, перебуваючи в обох світах одночасно, сама не здатна узгодити ці світи, проте вона $\epsilon$ єдиною істотою, яка перебуває в обох світах відразу. Жерменівська містифікація тексту на рівні лейтмотиву в цьому романі вирізняється також наголошенням на ймовірності-достовірності як хиткій межі людської свідомості. Відбувається навіть гра цією межею. Дійсність і 
містика повсякчас взаємно зумовлюються так само, як i взаємно заперечуються.

Перспективи подальших досліджень у цьому напрямі вбачаємо в тому, що проблематика роману «Погляд Медузи» Сильві Жермен, без перебільшення, універсальна й притаманна творчості чи не більшості авторів сучасності.

\section{ЛІТЕРАТУРА}

1. Жермен Сильви. Безмерность. - СПб.: «Амфора», 2003. - 221 с.

2. Жермен Сильви. Взгляд медузы. - СПб.: «Амфора», 2002. - 285 с.

3. Козловски Петер. Миф о модерне. Поэтическая философия Эрнста Юнгера. - Москва:Республика, 2002. - 234 с.

УДК $821.111 .09(73) ; 141.72$

DOI: $10.24144 / 2617-3921.2020 .18 .239-250$

Oksana Lutsyshyna

PhD, Lecturer in Ukrainian Studies, Department of Slavic and Eurasian Studies, University of Texas at Austin, USA oxana_flo@yahoo.com Olga Kishko Senior teacher of English Philology department Uzhhorod national university Orcid.org/0000- 003-1485-2653 Uzhhorod, Ukraine, $+38(050) 6786304$ olga.kishko@uzhnu.edu.ua

\section{Toni Morrison's Sula: queering binaries, uniting traditions}

Анотачія. Стаття розглядає роман Тоні Моррісон «Сула» з точки зору феміністської теорії $і$ квір-теорії. Роман викликав чимало дискусій у середовищі літературознавців $і$ культурологів. Вони розглянули складну структуру роману, гендерні стосунки, дружні стосунки між жінками, наголос на жіночій сексуальності, тощьо. Хоча дехто з досліднищь пропонував віднести роман до «лесбійської» літератури, ие викликало заперечення, тому що в романі немає сексуального контакту між жінками. У даній статті обстоюється думка, щяо доречніше підійти до твору з позииій квір-теорії, тобто континууму сексуальності, розмитості термінології, аніж з позицій 